\title{
The Effects of Human Capital on Agricultural Productivity and Farmer's Income in Cameroon
}

\author{
Jules Medard Nana Djomo (Corresponding author) \\ Faculty of Economic Sciences and Management, the University of Yaounde-II \\ P.O. BOX 1365 Yaounde, Cameroon \\ Tel: 237-99-84-3673Ｅ-mail: jdjomo81@yahoo.fr
}

Fondo Sikod

Faculty of Economic Sciences and Management, the University of Yaounde-II

P.O. BOX 1365 Yaounde, Cameroon

Tel: 237-77-50-0869_E-mail: fsikod2002@yahoo.com

Received: February 4, 2012

doi:10.5539/ibr.v5n4p149

\author{
Accepted: February 28, 2012 \\ Published: April 1, 2012 \\ URL: http://dx.doi.org/10.5539/ibr.v5n4p149
}

\begin{abstract}
This study evaluates how human capital affects agricultural productivity and farmer's income in Cameroon. Precisely, this study adopts methodologies that evaluate agricultural productivity, establish the stochastic frontier model and specify the returns to human capital. The database used to produce the empirical results is the Third Cameroonian Household Survey conducted by the National Institute of Statistics. Results obtained indicate that an additional year of experience and levels of education increases agricultural productivity. However, an additional year of experience squared denotes that the producer reduced his level of inefficiency. While an additional unit of education reduces the level of inefficiency. In addition, an additional year of education and years of experience squared increases farmer's income. To provide a solution to the problem of food insecurity, the government should allow farmers to endow more in human capital.
\end{abstract}

Keywords: Human capital, Agricultural productivity, Farmer's income

\section{Introduction}

The classical economists have identified land, labor and physical capital as the three basic factors of economic growth. In the 1960s neoclassical economists such as Schultz (1961) and Becker (1964) introduced the concept of human capital. They argue that the endowment of an educated society, trained and healthy workers allows the efficient use of factors Orthodox. They are followed by Mincer (1974) who suggested a simplified method for evaluating education. However, the idea that any investment in education has economic and social benefits in the long run, for both the individual and society as a whole, date back to Adam Smith, if not further.

For individuals, investment in human capital provides an economic return by increasing both the employment rate and labor income. We can prove this result by examining the levels of education, or by direct measures of human capital such as the results obtained in the capacity assessments of reading, writing and arithmetic. In addition to the benefits enjoyed by individuals, investment in human capital can be beneficial for the economy as a whole. In principle, it should be possible to discern the overall economic impact in the economic growth rate, but in practice it is difficult to confirm and quantify. The 2001 publication by the OECD helped to clarify in this regard and have shown that human capital also has many non-economic benefits. Thus, education tends to improve health. An additional year of schooling reduced according to the estimations, the daily consumption of cigarettes, and appears to promote happiness and fosters the education of the next generation. Children whose parents have completed the second cycle of secondary education are themselves more likely to go beyond high school, and are likely to easily associate themselves with greater participation in civic and volunteer activities, among others, granting of donations to charities, and a lower risk of delinquency. In addition, Timmer (2002) reports that in countries where the share of agriculture in gross domestic product (GDP) remains high, agricultural productivity can have an impact on total economic growth through "diverted and indirect links" related to human capital. Increasing the intensity coefficient of human capital can 
contribute directly to productivity gains at the farm level, facilitating the migration process by lowering costs and improving dietary energy intake that in turn promotes productivity.

The African continent is the only region of the developing world to continue experiencing difficulties after the green revolution of the 1970s and 1980s (Sanchez \& Sachs, 2004). The situation of the continent is far from brilliant agriculturally. Since the 1970s, food production per capita on the continent has been declining by about $20 \%$ (Ouedraogo, 2005). To reverse the decline of the agricultural sector on the continent, the Assembly of Heads of State and Government of the African Union ratified the Declaration on Agriculture and food security in Africa in Maputo in July 2003. This Declaration commits them to spend at least $10 \%$ of their budget to agriculture. Agricultural country such as Cameroon needs a sustained growth of agricultural production to feed its population and increase its export earnings. However, like most African countries, Cameroon's agriculture remains extensive and un-mechanized, implying the need for huge financing. Agricultural production is weak and fails to meet the food needs of populations. In addition, $60 \%$ of those in the agricultural sector and situated in rural areas are poor. This is due to low yields and difficulties in selling their products at remunerative prices. The isolation of the countryside induces high transaction costs that reduce the well-being. These people usually take a long time to attain basic infrastructures like tarred roads, markets, ware house facilities, etc. (INS, 2008). Building on the above observations, this study attempts to answer the following question: what is the effect of human capital on the mechanisms of production and income of agricultural producers in Cameroon? Specifically, what is the influence of human capital on agricultural productivity? How human capital affects farmer's income? To answer these questions the main objective of this study is to evaluate the impact of human capital on the mechanisms of production and income of farmers in Cameroon. We first present a literature review before proceeding to the methodology that will permit to generate results.

\section{Literature Review}

Human capital is the stock of competencies, knowledge and personality attributes embodied in the ability to perform labor so as to produce economic value. Human capital is vitally important for an organization's success (Crook et al., 2011); human capital increases through education and experience (Arthur \& Sheffrin, 2003). Many early economic theories refer to it simply as workforce, one of three factors of production, and consider it to be a fungible resource homogeneous and easily interchangeable. Other conceptions of this labor dispense with these assumptions. The use of the term in the modern neoclassical economic literature dates back to Mincer's article in 1958. Then Schultz is also contributed to the development of the subject matter. The best-known application of the idea of "human capital" in economics is that of Mincer and Becker of the "Chicago School" of economics. Becker's book published in 1964 became a standard reference for many years. In this view, human capital is similar to "physical means of production", e.g., factories and machines: one can invest in human capital (via education, training) and one's outputs depend partly on the rate of return on the human capital one owns. Thus, human capital is a means of production, into which additional investment yields additional output. Human capital is substitutable, but not transferable like land, labor, or fixed capital. Modern growth theory sees human capital as an important growth factor. Further research shows its relevance for democracy or AIDS (Hanushek \& Woessmann, 2008).

For over three centuries economists have been interested in valuing the productive capacity of the workers in an economy. This paper defines human capital as the stock of knowledge, skills, and abilities embodied in individuals that determines their level of productivity. In principle it includes innate abilities and skills acquired through education, training and experience. On a macro level, it is also common to measure the economy's human capital by the rates of enrolment in elementary and secondary schools and in post-secondary institutions. It is assumed that high enrolment rates in education and training institutions indicate that more people are accumulating human capital and that the workforce, as a whole, is becoming more productive. Indeed, countries with high enrollment rates in education and training institutions tend to enjoy higher productivity, higher living standards, and faster economic growth (Mankiw et al., 1992). Recent evidence, however, suggests that education does in fact increase productivity by improving individuals' skills. There is a strong and well-established positive relationship between educational attainment and labor earnings, which reflect productivity (Riddell, 2007). A simple correlation does not rule out the possibility that education captures the impact of an unobserved omitted variable, such as innate ability, but a large number of studies have used natural experiments to circumvent this problem (Note 1). These studies provide strong evidence that policy interventions that raised the educational attainment of certain groups in the past had large positive effects on the subsequent lifetime earnings of those individuals. This recent body of research gives rise to two key conclusions. First, rates of return to investments in education are high and possibly higher than what was implied by earlier research. Second, policy interventions that result in additional schooling being acquired by individuals from disadvantaged backgrounds, or those who face other barriers to acquiring human capital, may yield substantial returns in the form of enhanced productivity, in addition to contributing to equity objectives (Riddell, 2007). 
The neo-classical Human Capital theory emerged from the Growth Theory by Solow (1956) who took labor as an input and assumed constant return to scales in the production function. Solow's model was later criticized on the bases of the inequality between the rate of returns from human capital and physical capital and hence, Romer (1986) introduced the concept of increasing return to scales in order to equate the returns from human capital and the physical capital. But this view of human capital as a factor influencing productivity does not consider the possibility that some workers may be technically inefficient. In this case, the role of human capital may be biased during the valuing the production function. This paper addresses the two approaches namely on the one hand, the productivity from a production function Cobb-Douglas, which includes the total factor productivity (TFP) and on the other hand, the technical efficiency. In order to avoid such bias, it is necessary to use frontier techniques that consider the possible existence of inefficient behavior. Such is the case of the papers by Färe et al. (1994) on the analysis of TFP growth in the countries of the OECD, and by Tashkin and Zain (1997) on the importance of efficiency gains as a source of labor productivity convergence at an international level during the period 1975-1990.

Technical efficiency is a measure of a farm's productive performance. In the context of rural Cameroon, it can be defined as the ability of an agricultural household to obtain maximal output from a given set of inputs. Technical inefficiency should be considered as a measure of management error rather than a measure of income or gross output; higher inefficiency does not correspond to lower yields or less income. Human capital inputs have been recognized as critical factors in achieving recent sustained growth in productivity in some African countries (Schultz, 2003). Education may enhance technical efficiency directly by improving the quality of labor, by increasing the ability of farmers to adjust to disequilibria, and through its effect on input utilization (Moock, 1981). Literature on efficiency of productive units, which has been shaped by the seminal work of Farrell (1957), can be classified according to whether the measurement technique used is nonparametric or parametric. The development envelopment analysis (DEA) and the stochastic frontier analysis (SFA) are the most commonly non-parametric and parametric methods, respectively, used to measure the relative efficiency on farm-level data at one point in time (Note 2). Both the DEA and the SFA approaches recognize the possibility of inefficiency in production. They do not assume that all farmers are technically efficient. Being both extensively used in measuring production efficiency in agricultural sector of developing countries, the advantages and limits associated with these two competing methods, DEA and SFA, are briefly discussed (Note 3). Developed in 1978 by Charnes et al., the DEA method consists of mathematical programming formulations, where inefficient producing units are compared with the most efficient (best) units within the sample. The initial assumption of constant returns to scale was relaxed by Banker et al. (1984) to allow for variable returns to scale. The advantage of nonparametric techniques, such as the DEA, is that they do not rely on assumptions about the functional form or about the distribution of the error terms. The main limitation of the DEA method comes from its deterministic nature, which assumes that any deviation from the production frontier is due to inefficiency. Therefore, any measurement error and/or random stochastic error in the data are confounded with farmer inefficiency. As a result, the DEA estimates are very sensitive to the sample data, and especially to outliers (Greene, 1993). The SFA approach, which estimates the parametric form of a production function and recognizes the presence of random errors terms in the data, was first introduced by Aigner et al. (1977) and by Meeusen and van den Broeck (1977). This regression-based method incorporates a composed error term. One component of the error term reflects the inefficiency in production while the other component represents the random effects outside producer control, including luck, (un)favorable climate conditions, measurement error and other statistical noise from the data. The production frontier itself is stochastic since it varies randomly across farms due to the presence of the random error component (Coelli et al., 1999). Unlike the DEA method that estimates the best observed practice, the SFA approach econometrically estimates the best theoretical practice. The main criticism of this econometric technique is that strong assumptions have to be made concerning the selection of a particular functional form and the distribution of the inefficiency component in the composed error term. Nevertheless, the SFA model has the advantages of being able to measure the individual inefficiency in the presence of statistical noise in the dataset and to estimate standard errors. Given that both have virtues and shortcomings, the choice of an approach to measure efficiency becomes almost philosophical. Empirical studies on technical efficiency for farmers have used either the DEA (e.g., Gul et al., 2009; Helfand \& Levine, 2004; Audibert et al., 2003; Shafiq \& Rehman, 2000) or the SFA (e.g., Thirtle et al., 2003; Bravo-Ureta \& Evenson, 1994) or both (e.g., Chakraborty et al., 2002).

In this paper, the development of agricultural production functions takes into account the approach of Mincer's (1974) model of earnings. In other words, it integrates among the variables of agricultural production functions, those of education, experience level and training. This approach will allow us to see if a more productive agricultural producer also has a higher income level. Mincer's model of earnings (1974) is a cornerstone of empirical economics. It is the framework used to estimate returns to schooling (Ashenfelter \& Krueger, 1994; Ashenfelter \& Rouse, 1998), returns to schooling quality (Behrman \& Birdsall, 1983; Card \& Krueger, 1992) and to measure the impact of work experience on male-female wage gaps (Mincer \& Polachek, 1974). 


\section{Methodology}

\subsection{Data Source}

The database used in this research is the Third Cameroonian Household Survey conducted by the National Institute of Statistics in 2007. This database is the most recent on households in Cameroon. The survey's main objective is to assess the living standards of households in Cameroon. It provides a range of variables necessary to carry out this work, because it covers the whole of Cameroon and also provides information on the situation of producers by sector and by place of residence. It should be noted that we are interested to agricultural producers in rural areas. In other words, these are the farmers' heads of household. It should also be noted that the study carries of farm households, not agricultural industries. The total surveyed heads of farm households is 4275 .

\subsection{The Model of Agricultural Productivity}

Here we use the production function of the form Cobb-Douglas including human capital. This approach is borrowed from the Authors Bloom et al. (2001). These authors develop a production model that introduces the approach of Mincer (1974) of return of human capital and a factor called total factor productivity. However, the microeconomic and transversal context of this study requires the linear form of the production function as follows:

$$
\ln y_{i}=a_{j}+\sum_{i=1}^{n} \beta_{i} \ln x_{i j}+\alpha_{1} \text { nivins }_{j}+\alpha_{2} \text { format }_{j}+\alpha_{3} \exp _{j}+\alpha_{4} \exp _{j}^{2}
$$

Where, $\ln$ indicates the natural logarithm and the index $i$ and $j$, respectively, represents the inputs $i$ used by the farmer $\mathrm{j}$. In fact, $\mathrm{y}$ is actual output in monetary terms, $\alpha$ and $\beta$ vectors of parameters to be estimated. $\mathrm{a}$ is the total factor productivity and appears as an error term in the equation. This is an efficiency parameter which measures the efficiency of the production process. In this form, technical progress is assumed neutral as suggested by Hicks. This implies that technical progress increases the level of production (Note 4) that can be achieved with a given combination of inputs without affecting the marginal rate of substitution. Human capital of the producer is consisted by: nivins the number of years of education, by format to have received training $(1=$ yes and $2=$ no), exp level of experience (Note 5) and $\exp ^{2}$ experience squared (Note 6). More:

$\mathrm{y}=$ the value of agricultural production harvested on the farm given (in thousands of CFAF)

$\mathrm{x}_{1}=$ the total area used (ha)

$\mathrm{x}_{2}=$ the amount of work, which includes family and hired labor

$\mathrm{x}_{3}=$ the value of chemical fertilizer used in plantations (in thousands of CFAF)

$\mathrm{x}_{4}=$ the cost of pesticides used in production (in thousands of CFAF)

$\mathrm{x}_{5}=$ the capital, i.e., the amount of depreciation of equipment used in agricultural production (in thousands of CFAF)

$\mathrm{x}_{6}=$ the cost of labor employed (in thousands of CFAF)

$\mathrm{x}_{7}=$ the value of other operating expenses (in thousands of CFAF)

$\mathrm{x}_{8}=$ the cost of seed (in thousands of CFAF)

\subsection{The Model of Technical Efficiency}

From equation (1) which considers the importance of human capital as an additional factor production, uses the technical of non-frontier that ignores inefficiency. The model (2) below seeks to solve the above problems by incorporating human capital as an additional input and analyze its importance through the frontier's techniques, as a factor determining the rate of technical change. This avoids the possibility of bias from the non-incorporation of efficiency, which is derived from the omission of a relevant input. The stochastic frontier model is specified as follows:

$$
\ln y_{i}=\beta_{0}+\sum_{i=1}^{n} \beta_{i} \ln x_{i j}+v_{j}-u_{j}
$$

The error term $v_{j}$ is independent and identically distributed, and the term $u_{j}$ is distributed independently of $v_{j}$. The efficiency indicator obtained as the ratio of the optimal output and observed output is obtained from $\exp \left(u_{j}\right)$. The inefficiency can only reduce output below the frontier, it is necessary to specify the asymmetric distributions of the term inefficiency. Usually, we ensure that $v_{j}$ is normally distributed given that: $E\left(v_{j}\right)=0$ and $\operatorname{Var}\left(v_{j}\right)=\sigma_{v}^{2}$, and $u_{j}$ is assumed independently and identically distributed among the observations, and is obtained by truncation at point zero of the normal distribution where the average is defined by the equation:

$$
\mu_{j}=\delta_{0}+\delta_{1} \text { nivins }+\delta_{2} \text { format }_{j}+\delta_{3} \exp _{j}+\delta_{4} \exp _{j}^{2}+\varepsilon_{j}
$$


Where $\varepsilon_{\mathrm{j}}$ represents the random variable with mean zero and for unknown variance $\sigma^{2}$ and $\mathrm{u}_{\mathrm{j}}$ the non-negative error term $\left(u_{j} \geq 0, \forall \mathrm{j}\right)$, representing the technical inefficiency in the production of farmer $\mathrm{j}$. Equations (2) and (3) are jointly estimated by maximum likelihood technique. Using the value of agricultural production as endogenous variable rather than the physical quantities of the products is justified by the fact that some farmers practice mixed cropping on the same piece of land. Given the problems associated with the aggregation of these physical quantities to obtain all the yielding of the plot of culture, it is necessary to use the CFA franc as currency to get the value of outputs harvested. Indeed, some exogenous variables are also expressed in terms of value. This does not cause any statistical problem, since the endogenous variable is expressed in terms of value. In fact, the approach used here is largely derived from studies of authors such as Coelli et al. (1998), Ajibefun and Daramola (2004) and Nchare (2007), who have used the same method of conversion in their respective studies in situations where farmers have practiced a mixed cropping system.

\subsection{The Return Model}

As a reminder, several microeconomic studies of the effect of human capital on wages, based on the pioneering work of Mincer (1974), this empirical relationship appears under the transformed form as follows:

$$
\ln \text { Dep }_{j}=\gamma_{0}+\gamma_{1} \text { nivins }_{j}+\gamma_{2} \text { format }_{j}+\gamma_{3} \exp _{j}+\gamma_{4} \exp _{j}^{2}+\vartheta_{j}
$$

Where: $D e p_{j}$ is consumption expenditure (a proxy of income) of producer $j$, nivins his educational level, exp his experience and $\exp ^{2}$ his experience squared which determines the number of years in the job and $v_{j}$ the error term. Note that the semi-ln of the relationship (4) implies that the human capital variable introduces a multiplier effect that is better than the additive effect on wages. Accuracy relates to the salary. Studies in developing countries often use expenditure rather than measures based on the salary to capture access to resources because of the difficulty of collecting data of wages in economies where most of the labor working outside the formal labor market (Grootaert, 1999). In addition, income comes from agriculture and thus varies significantly within and through the years because of seasonality and weather shocks. The dependent variable in the equation (4) is the natural logarithm of consumption expenditure of the producer.

\section{Results of the Study}

Table 1 in annex indicates that on average, farmers use a plot of 2 hectares of land, employ on average 5 people for an average cost of $25000 \mathrm{CFAF}$. This expresses that some farmers are owners of small enterprises with low capital. While others farmers practice self-sufficiency food with a capital not reaching 1000 CFAF. This real fact is equally observed in the various costs, such as the cost of seed, the cost of pesticides, fertilizer costs and the cost of other operating expenses.

Also in Table 1 in annex, among the attributes of technical inefficiency, we denote the composite indexes of education and training. These composite indexes are obtained by the method of Multiple Correspondence Analysis (MCA). This method provides objective scores as opposed to subjective scores. This is a third variant of the factor analysis, namely the MCA as suggested, and presented by Asselin (2009). In addition, other attributes of technical inefficiency are experience and experience squared. That said there is years of experience up to 90 years and at minimum 0 years. The details of the setting of indexes are as follows: Level of education $1=$ No schooling, $2=$ Primary, $3=$ Secondary 1 st cycle, $4=$ Secondary 2 nd cycle, $5=$ Superior. A technical training or professional $1=$ Yes, $2=$ No.

According to the Fisher test, the model is globally significant at $1 \%$. The significance of each parameter is indicated by the Student test. The results are contained in Table 2 in annex. The surface area of land used relates positively to production. The increase of a unit of the cultivated area leads to an increase in production of $1.957 \%$. It is the same for the total number of agricultural workers. An additional worker augments production by $1.845 \%$. The cost of labor has no significant effect on production. Given that the cost of labor is zero for some farm households suggests that for these households, the labor is constituted by family members. The results of correlation study between the number of workers and the labor cost reveals a very weak correlation between these two exogenous variables. This indicates that an increase in the number of workers does not automatically increas the labor cost. Maybe labor cost is not efficient because of misspecification of this variable or data collecting problem. Similarly the cost of seed is weakly significant on the production. Even more, the cost of seeds is negatively correlated with the production. An additional unit of this cost tends to reduce output. If the seed is of poor quality, increased cost leads to a decrease in revenue from the sale of production. For cons, the cost of pesticides is rather positively correlated with the production. The increase a unit of cost of pesticides boosts the production of $0.878 \%$. One additional unit of cost of chemical fertilizers increases the production of $0.098 \%$. In addition, following the unit increase of the cost of other operating expenses, the production rises by $0.296 \%$. While the variation of an additional unit of capital at replacement cost increases the production of $0.030 \%$. Moreover, an additional year of experience reduces the production of $2.418 \%$. An additional year of 
experience squared increases the production of $2.296 \%$. In other words, experience squared reflects that at the long term, the producer becomes more productive. The composite index of the training has no impact on production. Moreover, the training cannot have an impact on production because the production depends on other factors such as the area of land cultivated, the type of seed, etc. It seems therefore appropriate to examine the impact of training on technical efficiency rather than production itself. Technical training received may be not consistent with the job that is exerted. Moreover, the results showed that the correlation between training and education is low. In addition, the regression method by successive elimination of variables allows us to find that the training had not significantly affect production. While the composite index of level of education indicates that additional endowment in education boosts the production of $11.078 \%$. Benhabib and Spiegel (1994) find the insignificant or negative coefficients for the variable of human capital in the production function. These authors conclude that human capital does not enter the production function as an input, but rather it influences growth through its effect on total factor productivity. The work of the OECD (2001) helped to clarify in this regard and have shown that in OECD countries, an additional year of education leads, on average and long-term, to an increase in per capita output.

If we materialize the total factor productivity by $\mathrm{A}$, we deduce that $\mathrm{A}=\exp (3.637424)=37.993838$ that is to say, the exponential of value of the constant. This result indicates that the increase of the production is determined by two components: the first are the factors of production and the second is a component A unexplained or residual that captures improvements of the technology.

The Table 3 in annex presents the results of the estimated parameters of the stochastic frontier model. Given that the Wald test follows a Chi-square with 8 degrees of freedom is significant at $1 \%$ according to the probability greater than chi-square is 0.0000 the model is well specified. In Table 3, the results of the production model are similar to those in Table 2. In other words, the interpretation of results follows the same analogy. Moreover, the model of inefficiency also presents similar results except for some differences in the signs. The first few years of experience are still years of productive inefficiency. An additional year of experience leads to a higher level of technical inefficiency of $2.443 \%$. But experience squared indicates that in the long term, the producer reduced his level of inefficiency of $2.325 \%$. The composite index of the training is not significant on production. In other words, technical training received by the producer does not allow it to influence the level of inefficiency. While an additional unit of composite index of level of education reduces the level of inefficiency of $11.034 \%$. It is shown that literacy of the producer increases efficiency and agricultural production could increase at the same level if all farmers were literate (Zonon, 2003). By cons, Gurgand $(1994,1997)$ found that education at a zero or even negative returns in agriculture in Ivory Coast. While Tilak (1993) and Coltear (1990) cited by Bako (2011) made a review of several studies in Asia and Europe showing that education significantly increases productivity.

The parameter of the variance composed is significantly different from zero at the $1 \%$ level. It is therefore necessary to analyze the standard deviation of inefficiency. The variance of the inefficiency is $\sigma_{u}^{2}=0.0000103$ and its standard deviation is the square root of its variance is $\sigma_{u}=0.0032093$. The low value of the standard deviation mentions that the dispersion of productive inefficiency around its mean is small. In other words, farmers in rural areas have the levels of inefficiency that are close.

The results of the return model are contained in Table 4 in Annex. The tests carry out on Fisher's statistic and the Student's statistic. The result of Fisher's test shows that the model is globally significant. While the Student's tests indicate that the parameters are significantly different from zero at the $1 \%$. Experience has a negative impact on income. If the producer accumulates one year of experience more his income reduces by $0.834 \%$. By cons, if the experience squared increases by one year, the income increases of $1.240 \%$. Note that the experience and experience squared have the opposite effect. As in the production models, experience squared has a positive effect in the return model. Indeed, given that the experience tends to decrease production, it will also tend to reduce income. Moreover, when the producer has one year of additional education, he increases his income of $25.863 \%$. For a producer who gets more training improves his income of $13.397 \%$. One notes thus the explanatory power of human capital on economic well-being. For UNDP (2001), the poverty rate in Sub-Saharan Africa is very high compared to other regions because of low adult literacy.

\section{Conclusion}

The objective of this paper was to evaluate the impact of human capital on the mechanisms of production and income of farmers in Cameroon. Results from the productivity model indicate that an additional year of experience reduces the production of $2.418 \%$. For an additional year of experience squared production increases by $2.296 \%$. In other words, experience squared reflects that in the long term, the producer becomes more productive. The variable training has no impact on the production. Technical training received by the farmer does not fit with his job. While an additional endowment in education boosts the production of $11.078 \%$. However, the conclusive results of technical efficiency 
model indicate that the early years of experience are still years of productive inefficiency. But experience squared indicates that, the producer reduced his level of inefficiency of $2.325 \%$. Equally training is not significant on production. In other words, the producer who received technical training is not technically efficient. While an additional unit of educational level reduces the level of inefficiency of $11.034 \%$. In addition, the model returns to human capital shows that experience has a negative impact on the income. By cons, an increase in experience squared allows the producer to increase his income of $1.240 \%$. As in models of productivity and technical efficiency, experience squared has a positive effect in the returns model. Indeed, because experience reduces agricultural production, expressed in monetary value, it will also tend to reduce income. However, one should be noted that this result is only meaningful when compared to the result of the effect of experience squared on agricultural production and income. In addition, an additional year of education increases the income of $25.863 \%$. For a producer who gets more training improves his income of $13.397 \%$.

The agricultural problem in the food aspect was also the main concern of the recent 34th General Assembly of the FAO which focus on global food security and is committed to halving the number of people suffering from hunger, nearly one billion by 2015 . To meet this challenge, it is necessary to improve productivity and agricultural production that can generate higher incomes for producers. Having reached the completion point for the initiative of heavily indebted poor countries and gaining thus a wide scope of its budget, Cameroon should choose agriculture as its main concerns. In fact, agriculture generates fiscal revenue and provides a wide range of raw materials to local manufacturers. In this prospect, ways to borrow for sustainable development of the agricultural sector are: First, government must place human capital before any other consideration. Because investment in human capital has future benefits evaluated in terms of greater productivity, efficient production process and yield more in terms of income level. Second, investment in agriculture is of great necessity, given that farming requires the use of chemical fertilizers, of pesticides, of seeds, of the land, of the labor, etc. The results of this study have shown that these investments boost agricultural production. Given this, to solve the problem of food insecurity in Cameroon which has worsened through the riots of the hungry in February 2008, it will important both improve productivity and agricultural production. However, the major action that should lead the government should be allowing farmers to be endow more in human capital: education, experience and training.

\section{References}

Aigner, D., Lovell, C., \& Schmidt, P. (1977). Formulation and estimation of stochastic frontier production function models. Journal of Econometrics, 6(1), 21-37. http://dx.doi.org/10.1016/0304-4076(77)90052-5

Ajibefun, A. I., \& Daramola, A. G. (2004). Efficiency of microenterprises in the Nigerian economy. African Economic Research Consortium (AERC), Nairobi Research Paper No. 134.

Arthur, S., \& Sheffrin, S. M. (2003). Economics: Principles in action (pp. 5). Upper Saddle River, New Jersey 07458: Pearson Prentice Hall.

Ashenfelter, O., \& Krueger, A. B. (1994). Estimates of the economic return to schooling from a new sample of twins. Quarterly Journal of Economics, 84(5), 1157-1173.

Ashenfelter, O., \& Rouse, C. (1998). Income, schooling and ability: evidence from a new sample of identical twins. Quarterly Journal of Economics, 113(1), 253-284. http://dx.doi.org/10.1162/003355398555577

Asselin, L. M. (2009). Analysis of Multidimensional Poverty: Theory and case studies. Ottawa, ON, CA: IDRC. http://dx.doi.org/10.1007/978-1-4419-0843-8

Audibert, M., Mathonnat, J., \& Marie-Claire, H. (2003). Social and health determinants of the efficiency of cotton farmers. Social Science \& Medecine, 56(8), 1705-1717. http://dx.doi.org/10.1016/S0277-9536(02)00164-8

Bako, D. (2011). Financement de l'agriculture et croissance agricole: cas du BURKINA FASO. Articles Directions de la Prospective et des Statistiques agricoles et Alimentaires (DPSAA) à des conférences scientifiques. pp. 3-24. Retrieved from http://www.countrystat.org/

Banker, R. D., Charnes, A., \& Cooper, W. W. (1984). Some models for estimating technical and scale efficiency in data envelopment analysis. Management Science, 30, 1078-1093. http://dx.doi.org/10.1287/mnsc.30.9.1078

Becker, G. (1964). Human Capital: A Theoretical and Empirical Analysis, with Special Reference to Education. NBER (National Bureau of Economic Research) and Columbia University Press.

Becker, G. S. (1994). Human Capital: A Theoretical and Empirical Analysis, with Special Reference to Education (3rd ed.). Chicago: University of Chicago Press.

Behrman, J., \& Birdsall, N. (1983). The quality of schooling: Quantity alone is misleading. American Economic Review, 73(5), 928-946. 
Benhabib, J., \& Spiegel, M. (1994). The role of human capital in economic development: evidence from aggregate cross-country data. Journal of Monetary Economics, 34, 143-173. http://dx.doi.org/10.1016/0304-3932(94)90047-7

Bloom, D. E., Canning, D., \& Sevilla, J. (2001). Health, Human Capital, and Economic Growth. CMH Working Paper Series, No. WG1: 8, 1-31.

Bravo-Ureta, B., \& Evenson, R. E. (1994). Efficiency in agricultural production: The case of peasant farmers in eastern paraguay. Agricultural Economics, 10, 27-37. http://dx.doi.org/10.1016/0169-5150(94)90037-X

Card, D., \& Krueger, A. (1992). Does school quality matter? Returns to education and the characteristics of public schools in the United States. Journal of Political Economy, 100(1), 1-40. http://dx.doi.org/10.1086/261805

Chakraborty, K., Sukant, M., \& Johnson, P. (2002). Cotton farmer technical efficiency: An application to stochastic and non-stochastic production approach. Agricultural and Resource Economics Review, 31(2), 211-220.

Charnes, A., Cooper, W. W., \& Rhodes, E. (1978). Measuring the efficiency of decision making units. European Journal of Operational Research, 2(6), 429-444. http://dx.doi.org/10.1016/0377-2217(78)90138-8

Coelli, T., Prasada, R., \& Battese, G. (1998). An Introduction to Efficiency and Productivity Analysis. Boston: Kluwer Academic Press. http://dx.doi.org/10.1007/978-1-4615-5493-6

Coelli, T. J., Perelman, S., \& Elliot, R. (1999). Accounting for environmental influences in stochastic frontier models: With application to international airlines. Journal of Productivity Analysis, 11, 251-273. http://dx.doi.org/10.1023/A:1007794121363

Coelli, T. J., Rao Prasada, D. S., O’Donnell, C. J., \& Battese, G. E. (2005). An Introduction to Efficiency and Productivity Analysis (2nd ed.). New York, NY: Springer.

Crook, T. R., Todd, S. Y., Combs, J. G., Woehr, D. J., \& Ketchen, D. J. (2011). Does human capital matter? A meta-analysis of the relationship between human capital and firm performance. Journal of Applied Psychology, 96(3), 443-456. http://dx.doi.org/10.1037/a0022147

Farrell, M. J. (1957). The measurement of productive efficiency. Journal of the Royal Statistical Society, 120(3), 253-290. http://dx.doi.org/10.2307/2343100

Greene, W. H. (1993). The Econometric Approach to Efficiency Analysis. In O. F. Harold, K. C. A. Lovell \& S. S. Schmidt (Eds.), The Measurement of Productive Efficiency: Techniques and Applications. New York: Oxford University Press.

Grootaert, C. (1999). Local Institutions and Service Delivery in Indonesia. mimeo. Social Development Department. Washington, DC: World Bank.

Gul, M., Koc, B., Dagistan, E., Akpinar, G. M., \& Oguz, P. (2009). Determination of technical efficiency in cotton growing farms in Turkey: A case study of Cukurova Region. African Journal of Agricultural Research, 4(10), 944-949.

Hanushek, E., \& Woessmann, L. (2008). The role of cognitive skills in economic development. Journal of Economic Literature, 46, 607-668. http://dx.doi.org/10.1257/jel.46.3.607

Helfand, S. M., \& Edward, S. L. (2004). Farm size and the determinants of productive efficiency in the Brazillian Center West. Agricultural Economics, 31, 241-249. http://dx.doi.org/10.1111/j.1574-0862.2004.tb00261.x

Institut National de la Statistique (INS). (2008). Tendances, profil et déterminants de la pauvreté au Cameroun en 2007. Rapport de l'Enquête ECAM III, Yaoundé.

Mankiw, N. G., Romer, D., \& Weil, D. (1992). A contribution to the empirics of economic growth. Quarterly Journal of Economics, 107(2), 407-437. http://dx.doi.org/10.2307/2118477

Meeusen, W., \& Van Den Broeck, J. (1977). Efficiency estimation from Cobb-Douglas oroduction functions with composed error. International Economic Review, 18(2), 435-444. http://dx.doi.org/10.2307/2525757

Mincer, J. (1958). Investment in human capital and personal income distribution. Journal of Political Economy, 66(4), 281-302. http://dx.doi.org/10.1086/258055

Mincer, J. (1974). Schooling, experience and earnings. New York: NBER and Columbia University Press.

Mincer, J., \& Polachek, S. (1974). Family investment in human capital: Earnings of women. Journal of Political Economy, 82 (2, part II), S76-S108. http://dx.doi.org/10.1086/260293

Moock, P. R. (1981). Education and technical efficiency in small-farm production. Economic Development and Cultural Change, 29(4), 723-739. http://dx.doi.org/10.1086/451287 
Nchare, A. (2007). Analysis of factors affecting the technical efficiency of Arabica coffee producers in Cameroon. The African Economic Research Consortium, Paper No. 163.

Oreopoulos, P. (2006). The compelling effects of compulsory schooling: Evidence from Canada. Canadian Journal of Economics, 39(1), 22-52. http://dx.doi.org/10.1111/j.0008-4085.2006.00337.x

Organisation de Coopération et de Développement Economiques (OCDE). (2001). Du bien-être des nations: Le rôle du Capital Humain et Social. Rapport publié par le Centre pour la recherche et l'innovation dans l'enseignement de l'OCDE, pp.138.

Ouédraogo, S. (2005). Intensification de l'agriculture dans le Plateau Central du Burkina Faso: une Analyse des possibilités à partir des nouvelles technologies. (Doctoral dissertation). Rijksuniversiteit Groningen, pp. 336.

Programme des Nations Unies pour le Développement (PNUD). (2001). Mettre les nouvelles technologies au service du développement. Rapport sur le Développement Humain. De Boeck Université.

Riddell, W. C. (2007). The Impact of Education on Economic and Social Outcomes: An Overview of Recent Advances in Economics. In G. Picot, R. Saunders \& A. Sweetman (Eds.), Fulfilling Potential, Creating Success: Perspectives on Human Capital Development. Montreal and Kingston: McGill-Queen's University Press.

Romer, P. M. (1986). Increasing returns and long run growth. Journal of Political Economy, 94, 1102-1037. http://dx.doi.org/10.1086/261420

Sanchez, P., \& Sachs, J. (2004). Une révolution verte pour l'Afrique. le Monde, du 10 août 2004.

Schultz, T. P. (2003). Wage rentals for reproducible human capital: Evidence from Ghana and the Ivory Coast. Discussion Paper 868. New Haven, Conn.: Economic Growth Center, Yale University.

Schultz, T. W. (1961). Investment in human capital. American Economic Review, 51(1), 1-17.

Shafiq, M., \& Rehman, T. (2000). The extent of resource use inefficiencies in cotton production in Pakistan's Punjab: An application of data envelopment analysis. Agricultural Economics, 22, 321-330. http://dx.doi.org/10.1111/j.1574-0862.2000.tb00078.x

Solow, R. M. (1956). A contribution to the theory of economic growth. Quarterly Journal of Economics, 70(1), 65-94. http://dx.doi.org/10.2307/1884513

Taskin, F., \& Zaim, O. (1997). Catching-up and innovation in high- and low-income countries. Economic Letters, 54, 93-100. http://dx.doi.org/10.1016/S0165-1765(97)00004-9

Thirtle, C., Beyers, L., Ismael, Y., \& Jenifer, P. (2003). Can GM-Technologies Help the Poor. The Impact of BT Cotton in Makhathini Flats, KwaZulu-Natal. World Development, 31(4), 717-732. http://dx.doi.org/10.1016/S0305-750X(03)00004-4

Timmer, C. P. (2002). Agriculture and Economic Development. In B. Gardner \& G. Rausser (Eds.), Handbook of Agricultural Economics (vol. 2). Elsevier Science B.V.

Zonon, A. (2003). Education et productivité des agriculteurs. Cas des producteurs du Burkina Faso (pp. 50). Dakar: UEPA.

\section{Notes}

Note 1. A natural experiment exploits variation in educational attainment that is caused by some force unrelated to a person's individual characteristics. For example, interprovincial differences in compulsory schooling laws (i.e. the age at which one can drop out of high school) can affect educational attainment but are not related to individual students' characteristics (Oreopoulos, 2006). This allows for the use of statistical techniques that measure the impact of educational attainment without being biased by the unobservable individual characteristics.

Note 2. In addition to cross-sectional data, both the DEA and SF methods can also be used to measure efficiency on panel data.

Note 3. See Coelli et al. (2005) for a more comprehensive discussion on both methods.

Note 4. Shifts the production curve.

Note 5. Measured in number of years spent in agricultural production.

Note 6. Which captures the long term. 
Table 1. Descriptive Statistics of the Exogenous Variables

\begin{tabular}{llllll}
\hline Exogenous variables & Valid N & Mean & Std. Deviation & Minimum & Maximum \\
\hline Total area harvested & 4134 & 2.391081 & 3.577036 & 0 & 90 \\
Total number of employees & 4143 & 4.641933 & 3.92388 & 0 & 60 \\
Cost of labor & 4226 & 24.54146 & 226.677 & 0 & 14200 \\
Cost of seed & 4216 & 9.743039 & 92.18885 & 0 & 4000 \\
Cost of pesticides & 4219 & 9.18484 & 28.77979 & 0 & 610 \\
Fertilizer costs & 4200 & 17.93365 & 70.34361 & 0 & 2100 \\
Cost of other expenses & 4106 & 9.691457 & 32.34727 & 0 & 836 \\
Capital replacement cost & 4097 & 16.92161 & 112.2208 & 0 & 5000 \\
Years of Experience & 4220 & 36.67856 & 15.05384 & 0 & 90 \\
Years of experience square/100 & 4220 & 15.71924 & 12.30989 & 0 & 81 \\
IC Technical Training & 4188 & .4544914 & .3473862 & 0 & .72 \\
IC education & 4275 & 1.565083 & .5536479 & 0 & 2.18 \\
\hline Endogenous variables & & & & & 11.51 \\
Logarithm of the production & 4275 & 3.646636 & 1.583652 & 0 & 14.83 \\
Logarithm of per capita consumption expenditure & 4275 & 12.3518 & .60222 & 11.19 & \\
\hline
\end{tabular}

Source: Results from the Study.

Table 2. Parameters Estimated of the Productivity Model

\begin{tabular}{lllll}
\hline Ln Production & Coef. & Robust Std. Error & t & $\mathbf{P}>|\mathbf{t}|$ \\
\hline Total area harvested & .0195738 & .007198 & 2.72 & 0.007 \\
Total number of workers & .0184545 & .0063996 & 2.88 & 0.004 \\
Cost of labor & .0003377 & .0003164 & 1.07 & 0.286 \\
Cost of seed & -.0002939 & .000226 & -1.30 & 0.193 \\
Cost of pesticides & .0087865 & .0010754 & 8.17 & 0.000 \\
Cost of chemical fertilizers & .0009836 & .0004458 & 2.21 & 0.027 \\
Cost of other expenses & .0029653 & .0009972 & 2.97 & 0.003 \\
Capital replacement cost & .0003079 & .0001742 & 1.77 & 0.077 \\
Experience & -.0241887 & .0074222 & -3.26 & 0.001 \\
Experience squared & .0229694 & .0090257 & 2.54 & 0.011 \\
Composite index of training & .0200252 & .0710621 & 0.28 & 0.778 \\
Composite index of education & .110788 & .0449546 & 2.46 & 0.014 \\
Constant & 3.637424 & .160051 & 22.73 & 0.000 \\
\hline Linear regression & & & Number of observations $=4097$ \\
F(12, 4 084)=23.01 & & & Prob $>$ F $=0.0000$ \\
R-square=0.0897 & & & Root MSE $=1.4902$ \\
\hline
\end{tabular}

Source: Results from the Study. 
Table 3. Estimated Parameters of the Stochastic Model

\begin{tabular}{|c|c|c|c|c|}
\hline Ln production & Coef. & Std. Error & $\mathbf{z}$ & $\mathbf{P}>|\mathbf{z}|$ \\
\hline \multicolumn{5}{|l|}{ Production model } \\
\hline Total area harvested & .0195732 & .0053254 & 3.68 & 0.000 \\
\hline Total number of workers & .0184924 & .0067379 & 2.74 & 0.006 \\
\hline Cost of labor & .0003376 & .0002265 & 1.49 & 0.136 \\
\hline Cost of seed & -.0002939 & .0004169 & -0.70 & 0.481 \\
\hline Cost of pesticides & .0087869 & .0007086 & 12.40 & 0.000 \\
\hline Cost of chemical fertilizers & .0009826 & .000428 & 2.30 & 0.022 \\
\hline Cost of other expenses & .0029659 & .0007847 & 3.78 & 0.000 \\
\hline Capital replacement cost & .0003077 & .0001845 & 1.67 & 0.095 \\
\hline Constant & 3.729433 & .1945262 & 19.17 & 0.000 \\
\hline \multicolumn{5}{|l|}{ Mu } \\
\hline Experience & .0244326 & .0067961 & 3.60 & 0.000 \\
\hline Experience squared & -.0232521 & .0081742 & -2.84 & 0.004 \\
\hline Composite index of training & -.0211718 & .0707032 & -0.30 & 0.765 \\
\hline Composite index of education & -.1103451 & .0452089 & -2.44 & 0.015 \\
\hline Constant & .0874389 & .1804336 & 0.48 & 0.628 \\
\hline \multicolumn{5}{|l|}{ Variance parameters } \\
\hline$/ \operatorname{Ln} \sigma^{2}$ & .7946506 & .0220937 & 35.97 & 0.000 \\
\hline /ilgtgamma & -12.27775 & 29.00987 & -0.42 & 0.672 \\
\hline$\sigma^{2}$ & 2.213667 & .048908 & & \\
\hline$\gamma=\frac{\sigma_{u}^{2}}{\sigma^{2}}$ & $4.65 \mathrm{e}-06$ & .000135 & & \\
\hline$\sigma_{u}^{2}$ & .0000103 & .0002989 & & \\
\hline$\sigma_{v}^{2}$ & 2.213657 & .0489082 & & \\
\hline \multicolumn{3}{|c|}{ Stochastic. frontier normal/truncated-normal model } & \multicolumn{2}{|c|}{ Number of observations $=4097$} \\
\hline Wald chi2 $(8)=367.16$ & \multicolumn{2}{|c|}{ Prob $>$ chi $2=0.0000$} & ihood $=$ & 774 \\
\hline
\end{tabular}

Source: Results from the Study.

Table 4. Estimated Parameters of the Return Model

\begin{tabular}{lllll}
\hline Ln consumption expenditure & Coef. & Robust Std. Error & t & $\mathbf{P}>|\mathbf{t}|$ \\
\hline Experience & -.0083415 & .0017684 & -4.72 & 0.000 \\
Experience squared & .0124008 & .0030731 & 4.04 & 0.000 \\
Composite index of education & .258631 & .0190673 & 13.56 & 0.000 \\
Composite index of training & .133975 & .0283176 & 4.73 & 0.000 \\
Constant & 12.9058 & .0303598 & 425.10 & 0.000 \\
\hline Linear regression & & & Number of observations $=4155$ \\
F $(4,4150)=100.11$ & & Prob $>$ F $=0.0000$ \\
R-square $=0.0895$ & & Root MSE $=.57524$ \\
\hline
\end{tabular}

Source: Results from the Study. 